\section{Money oils the wheels}

SINCE 1983, France has offered industrial and commercial enterprises an abatement of their tax bills on account of the research they carry out or otherwise support, but on a formula devised by Jean-Pierre Chevènement that must often seem a little like that of the mediaeval torture apparatus called the rack. The tax credit is calculated not on the basis of what enterprises spend in the relevant year, but on the extent to which their research spending has increased from one year to the next.

How well has the system worked? A study last year by two industrialists (Jean Cantacouzene, director of research at the oil-company Total, and Pascal Gendreau, joint director-general of the government organization for small and middle-sized business) has shown that the system at least provides a means by which the government can get to learn of the changing pattern of research in different kinds of industries.

One surprising finding is that tax credits tend to be a larger proportion of total research spending in traditional industries, such as furniture and textile manufacture and in food processing, than in high-technology industries, no doubt because the companies choosing to register for credits now have only recently embarked on such research.

The system is also cunningly biased against large enterprises. Of 346 companies with turnover exceeding FF500 million applying for tax credits in 1987, the credits eventually awarded amounted to only 2.5 per cent of total research spending, compared with 12.8 per cent for the 3,682 companies with a turnover of less than FF500 million. It also seems that the smaller businesses constitute the fastest growing of the tax authorities' applicants, suggesting that the scheme serves its purpose of spreading the research culture.

The figures brought to light by the taxcredit scheme are part of the basis for the government's assertion that French industry is still spending less on research and development than it should be. The report of the Cantacouzene-Gendreau study concludes that industrial research is some 0.5 per cent of GDP less than it should be if France is to keep up with West Germany and Japan in relative terms. That deficit amounts to FF25,000 million a year at present.

Overall, the numbers of companies benefiting from the tax credit system multiplied fivefold between 1983 and 1989 , to an estimated 7,000 (the returns are not yet complete). The cost to the Treasury is estimated to have been FF2,600 million last year - but the cost of administering the system is said to have been "derisory".

For the future, it seems to be agreed that the scheme should be given more publicity, and that the government should agree to make it permanent. Already it has been conceded that companies making substantial research expenditures in a single year should be able to spread the funds over several years.

\title{
Can government back winners?
}

FRANCE has taken a long hard look at Japan's success, and wishes it could follow suit. But, with French industry not willing to shoulder the responsibility for spending what it might, the government has become the initiator of last resort.

That seems to be the philosophy on which the French government is now working, and the explanation for the substantial support for industrial research over the past two years. Between them, the research and the industry ministries will this year spend about FF5,000 million on industrial research of a general character, quite apart from the best part of FF6,000 million spent on research at the $\mathrm{CEA}$ and other mission-orientated research organizations concerned with space, aeronautics and the like. The largest single increase in the research ministry's budget for the present year 30 per cent - takes its general fund for industrial research to FF1,565 million.

There have always been hankerings in that direction. The legend of the French nuclear energy industry began that way, with a deliberate decision to found a new industry with research and development. Did not France also invent EUREKA (in 1983) as a way of persuading other European states to invest funds in high technology?

Research minister Hubert Curien leaves no room for doubt that the sponsorship of industrial research is his priority for 1990 , as it has been for the past two years. The emphasis will be on the search for new products and processes, to which the ministry expects to commit FF300 million this year, on perhaps 40 projects. The chosen fields are in new materials and food technology and biotechnology.

Two other goals have high priority, of which the more ambitious is that France should make a mark in the development of high-definition television (HDTV). It is only a small part of the calculation that France itself is likely to be a natural market for devices that bring the clarity of the cinema-screen into every living room.
More relevant to the choice of this priority is France's conception of itself as Europe's research strategist. There have been several occasions in the past 30 years when France has invested its own funds in huge technical projects it could not hope to carry through on its own, in competition with other players on the international markets, but which have been strategically important for Europe.

Nuclear energy is such a case. Although there has been a brief pause in French reactor construction (see page 139), if some would say when - there should be a revival of demand for nuclear generating capacity in Europe, French nuclear contractors may be better placed than others to win orders from European utilities.

Much the same has happened in aeronautics and space launching, where French investment in research has been used (together with political persuasion) to prompt the formation of international companies that manufacture civil aircraft and offer space launching facilities (Airbus Industrie and Arianespace respectively). In each case, the objective has been to create a European counterpoise to a de facto US monopoly.

French support for HDTV is, rather, directed eastwards. From the outset of the EUREKA scheme, several projects have been directed at the processing of digital representations of video images, the basis of schemes for radically improving video definition. Non-French companies such as Siemens (West Germany) and Philips (Netherlands) have been closely involved from the beginning. But nobody should be surprised if official French enthusiasm for HDTV - the EUREKA rules allow governments to contribute towards companies' research expenses - culminates in a proposal for a joint European venture to head off the Sony's of this world.

The processing of silicon wafers is the research ministry's other immediate goal. The code-name is JESSI (for Joint European Submicron Silicon). The immediate goal is to make a 1-Gbyte memory chip, but the hidden agenda might be to make a supercomputer on a single chip. Modest Hubert Curien's ministry will acquire clout (perhaps even kudos) if the enterprise succeeds because of its ability (relative to that of comparable European ministries) to urge its client companies towards investment by offering (sometimes threatening) to spend its own money.

For the rest, the ministry plans to concentrate on small and middle-sized companies, traditionally cared for by a state agency called ANVAR (for Agence National de Valorisation de la Recherche), whose budget has been increased by 10 per cent this year. It will be interesting to see, a year from now, how many of those intermediate companies are in the business of high technology. The guess of 100 per cent will not be far from the mark. 